\title{
First record of the harp seal (Pagophilus groenlandicus) extralimital presence in the Mediterranean Sea
}

\author{
J.J. BELLIDO ${ }^{1,6}$, J. CABOT ${ }^{2}$, J.J. CASTILLO ${ }^{1}$, J.C. BÁEZ ${ }^{3}$, J.J. MARTÍN ${ }^{1}$, J.L. MONS ${ }^{1}$, J. LARIOS ${ }^{4}$, J. RUBIA $^{5}$ \\ AND R. REAL ${ }^{6}$ \\ ${ }^{1}$ Aula del Mar de Málaga, Málaga, Spain, ${ }^{2}$ Estación Biológica de Doñana, Sevilla, Spain, ${ }^{3}$ Instituto Español de Oceanografía (IEO), \\ Centro Oceanográfico de Málaga, Spain, ${ }^{4}$ Asociación Buxus, Motril, Spain, ${ }^{5}$ Grupo Ecologista Alboran, Motril, Spain, \\ ${ }^{6}$ Departamento de Biología Animal, Facultad de Ciencias, Universidad de Málaga, E-29071, Spain
}

\begin{abstract}
The stranding of a harp seal on the beach in the municipality of Motril (southern Spain) represents the first record of this species in the Mediterranean Sea and the southernmost known report. It was a male which reached the beach very tired and sick, dying after two hours on the sand. The specimen presented three species of epibionts. This is the second species of Arctic seal recorded in the Mediterranean Sea.
\end{abstract}

Keywords: harp seal, Mediterranean Sea, stranding, epibionts

Submitted 12 September 2009; accepted 15 October 2009

The harp seal Pagophylus groenlandicus (Erxleben, 1777) is the most usual species in the North Atlantic (Folkow et al., 2004). This species consists of three populations with three independent breeding grounds, the north-west Atlantic, the Greenland Sea and the White Sea/Barents Sea population (Folkow et al., 2004; Nordøy et al., 2008). The north-west Atlantic population breeds in the Gulf of St Lawrence and off the coasts of Labrador and Newfoundland. The East Greenland population breeds near Jan Mayen Island, and the Barents Sea population breeds in the White Sea. After breeding, harp seals carry out important migratory journeys, always in waters of the North Atlantic and mainly around the Barents Sea (Kovacs, 2008; Nordøy et al., 2008).

Five other species of Arctic seals have been reported in Atlantic waters next to the Strait of Gibraltar (Avellá et al., 1993; Bree, 1997), but only the hooded seal Cystophora cristata (Erxleben, 1777) was previously reported inside the Mediterranean Sea (Bellido et al., 2007). There are no prior reports of harp seal occurrence in the Mediterranean basin.

On 26 September 2008, one harp seal was found stranded (Figure 1) in Motril $\left(36^{\circ} 41^{\prime} \mathrm{N} 3^{\circ} 29^{\prime} \mathrm{W}\right)$ Granada, Spain, inside the Mediterranean Sea (Figure 2). This specimen was a male with a total length of $170 \mathrm{~cm}$ and a weight of $61.5 \mathrm{~kg}$. External anatomical characters and dental formula were used to determine the species of seal. The animal was very sick, extremely thin, with external injuries and presented three species of epibionts (Cirripedia: Lepas hilli Leach, 1818; Conchoderma virgatum, Spengler, 1790; Conchoderma auritum, Linnaeus 1767) (Figure 3) which may be a signal of a long period of weakness (Aznar et al., 2005) with slow swimming. However, the epibiotic relation between species of genus Conchoderma and high migratory pelagic animals

Corresponding author:

J.J. Bellido

Email: jjbellido@auladelmar.info such as swordfish Xiphias gladius (Linnaeus, 1758), bluefin tuna Thunnus thynnus (Linnaeus, 1758) or whales is not unusual in the Mediterranean Sea (i.e. Báez et al., 2003). Nevertheless, we did not find reports of similar cases in seals.

The harp seal died on the beach while it was being treated by the emergency team. McAlpine \& Walker (1990) found a low rate of survival in extralimital strandings and sightings on the east coast of the USA, and suggested that this is common in specimens that leave their usual ranges of feeding and breeding and spend the summer in southern waters.

During the necropsy stones and sand were found in the stomach, as well as cephalopods and nematodes. The finding of stones in the stomach is not unusual in this species and it may be related to an aid in the physical breakdown of fish flesh and hard fish bones (Nordøy et al., 1995). The presence of sand and stones in the stomach has been also confirmed in two specimens of hooded seal stranded on the Mediterranean Spanish coast (Mons et al., 1999; Bellido et al., 2007).

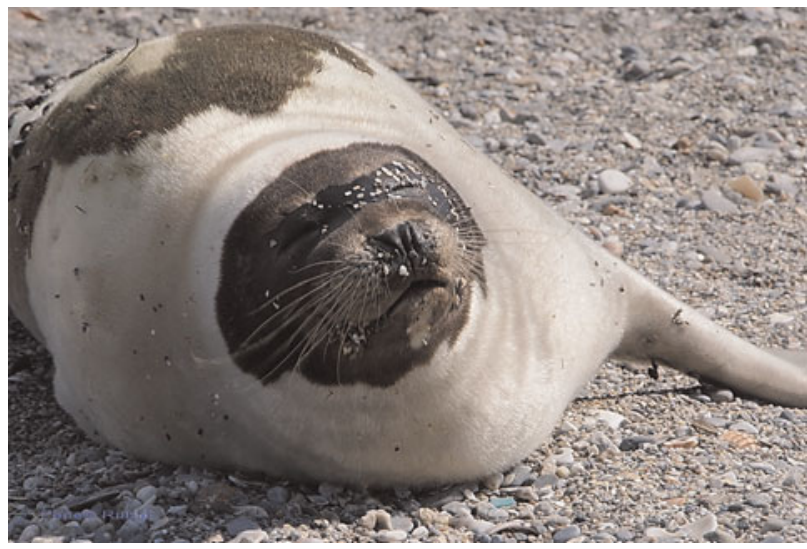

Fig. 1. Harp seal stranded in Motril (southern Spain). 


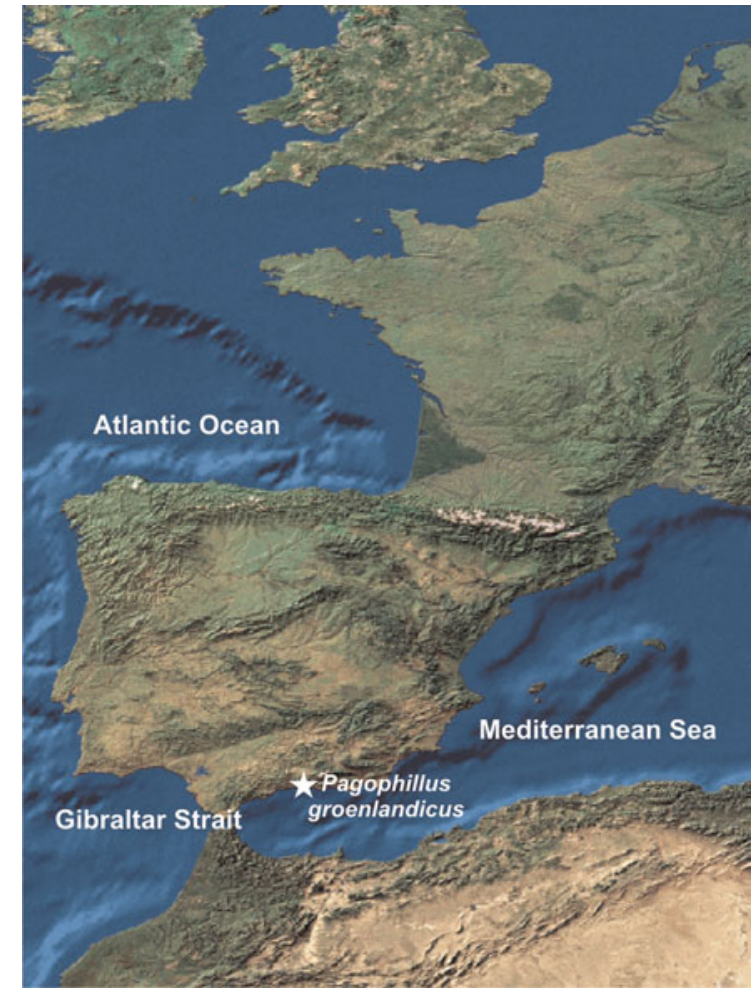

Fig. 2. Location of the harp seal stranding in the Mediterranean Sea.

Samples of skin, fat tissue, and muscle are kept in the Aula del Mar of Málaga (Spain) under the control of the Consejería de Medio Ambiente de la Junta de Andalucía (Andalusian Government), and the skull is housed in the Vertebrate Collection of the Estación Biológica de Doñana.

This sighting constitutes the southernmost known report for the harp seal worldwide, and could be put in the context of the unusual increase of extralimital records of harp seal reported by McAlpine et al. (1999) in the Gulf of Maine (north-west Atlantic) since the end of the past century. According to MacAlpine et al. (1999) 'invasion years' could be impelled by fish stock collapses which would force seals to travel south in search of food or by demographic explosions leading to greater numbers of extralimital animals. Indeed, Gjøsæter et al. (2009) reported a recent collapse of the capelin, Mallotus villosus Müller, 1776, stock in the Barents Sea, which is the principal prey of harp seals (Nordøy et al., 2008).

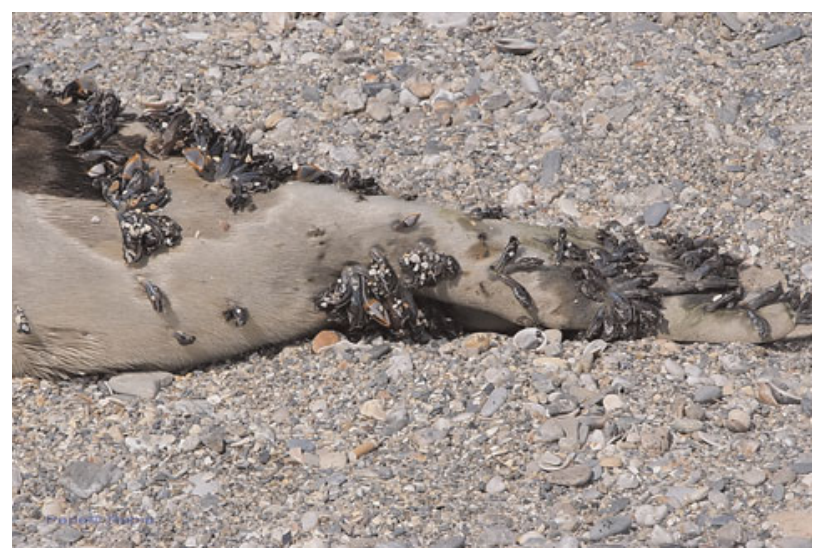

Fig. 3. Epibiont organisms on the stranded harp seal.

\section{ACKN口WLEDGEMENTS}

Data from strandings have been lent by the Consejería de Medio Ambiente de la Junta de Andalucía (Andalusian Government) and the staff of the Vertebrate Collection of the Estación Biológica de Doñana (EBD). This study was partially funded by the project CGL2006-09567/BOS (Ministerio de Ciencia y Tecnología, Spain, and FEDER).

\section{REFERENCES}

Avellá F., Castells A. and Mayo M. (1993) Los pinnipedos de las costas atlánticas y cantábricas de la península ibérica. Quercus 85, 29-34.

Aznar F.J., Perdiguero D., Pérez del Olmo A., Repullés A., Agustí C. and Raga J.A. (2005) Changes in epizoic crustacean infestations during cetacean die-offs: the mass mortality of Mediterranean striped dolphins Stenella coeruleoalba revisited. Diseases of Aquatic Organisms 67, 239-247.

Báez J.C., De la Serna J.M., Macias D. and Flores-Moya A. (2003). Notas sobre las macroalgas epizoicas que crecen sobre la espada de Pez espada, Xiphias gladius (Linnaeus, 1758) (Teleostei, Xiphidae), capturado en el Mediterráneo occidental. Boletín de la Real Sociedad Española de Historia Natural (Sección Biológicas) 98, 5-7.

Bellido J.J., Castillo J.J., Martín J.J., Mons J.L., Farfán M.A. and Real R. (2007) First records of hooded seals (Cystophora cristata) in the Mediterranean Sea. Marine Biodiversity Records 1. Published online by Cambridge University Press.

Bree P.H.J. (1997) On extralimital records of arctic seals (Mammalia, Pinnipedia) on the West European continental coast in the past and at present. A summary. Beaufortia 47, 153-156.

Folkow L.P., Nordøy E.S. and Arnoldus S.B. (2004) Distribution and diving behaviour of harp seals (Pagophilus groenlandicus) from the Greenland Sea stock. Polar Biology 27, 281-298.

Gjøsæter H., Bogstad B. and Tjelmeland S. (2009) Ecosystem effects of the three capelin stock collapses in the Barents Sea. Marine Biology Research 5, 40-53.

Kovacs K. (2008) Pagophilus groenlandicus. 2008 IUCN Red List of Threatened Species. <www.iucnredlist.org $>$. Downloaded on 26 January 2009.

Mcalpine D.F. and Walker R.J. (1990) Extralimital records of the harp seal, Phoca groenlandica, from the western North Atlantic: a review. Marine Mammal Science 6, 248-252.

Mcalpine S.F., Stevick P.T. and Murison L.D. (1999) Increase in extralimital occurrences of ice-breeding seals in the northern gulf of Maine region: more seals or fewer fish? Marine Mammal Science 15, 906-911.

Mons J.L., Martín J.J. and Castillo J.J. (1999) Presencia de varias focas en el litoral andaluz. Libro de actas de las IV Jornadas Españolas de Conservación y Estudio de Mamíferos. Segovia, 5-7 Diciembre 1999.

Nordøy E.S. (1995) Gastroliths in the harp seal Phoca groenlandica. Polar Research 14, 335-338.

and

Nordøy E.S., Folkow L.P., Potelov V., Prischemikhin V. and Blix A.S. (2008) Seasonal distribution and dive behaviour of harp seals (Pagophilus groenlandicus) of the White Sea-Barents Sea stock. Polar Biology 31, 1119-1135.

\section{Correspondence should be addressed to:}

J.J. Bellido

Departamento de Biología Animal

Facultad de Ciencias, Universidad de Málaga

E-29071, Spain

email: jjbellido@auladelmar.info 